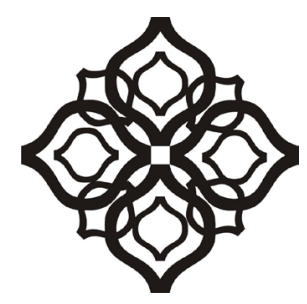

Shirkah

Journal of Economics and Business 


\section{Shirkah}

Journal of Economics and Business

Vol. 4, No. 1, January-April 2019

ISSN: 2503-4235 (p); 2503-4243 (e)

\section{Editor in Chief}

Fitri Wulandari

\section{Managing Editor}

Jasanta Peranginangin

\section{Editorial Boards}

Abdul Azim Islahi, Islamic Economics Institute, King Abdulaziz University, Saudi Arabia Abu Umar Faruq Ahmad, UBD School of Business and Economics Universiti, Brunei Darussalam Cedomir Nestorovic, ESSEC Business School Asia Pacific, Singapore

Fitri Wulandari, Faculty of Islamic Economics and Business, IAIN Surakarta, Indonesia Johan Fischer,

Department of Social Sciences and Business Roskilde Universitetscenter, Denmark Muhamed Zulkhibri, Islamic Research and Training Institute, Islamic Development Bank, Saudi Arabia M. Kabir Hassan,

Department of Economics and Finance, University of New Orleans, United States Musa Asy'arie,

Faculty of Islamic Economics and Business, IAIN Surakarta, Indonesia Nunung Nurul Hidayah, Aston Business School, Aston University, Birmingham, United Kingdom Saim Kayadibi,

Department of Economics, Kulliyyah of Economics and Management Science, International Islamic University Malaysia, Malaysia 
Shaikh M Ghazanfar,

Departement of Economics, University of Idaho, Russian Federation

Sigit S. Wibowo,

Department of Management, Faculty of Economics and Business, Universitas Indonesia, Indonesia

Vihang R. Errunza,

Desmarais Global Finance Research Centre, Desautels Faculty and Management, McGill University, Canada

\section{Assistant to Editor \\ M. Endy Saputro \\ M. Zainal Anwar}

Shirkah Journal of Economics and Business is a peer-reviewed journal published three times a year (January-April, May-August and September-December) by Faculty of Islamic Economics and Business, Institut Agama Islam Negeri (IAIN) Surakarta Central Java, Indonesia. The main objective of Shirkah is to offer an academic space of exchange ideas and initiate the increase number of qualified article produced by postgraduate students, practitioners and academicians.

\section{Editorial Office}

Ruang Jurnal Shirkah

Lantai Dasar, Sayap Barat, Fakultas Ekonomi dan Bisnis Islam, IAIN Surakarta

Jln. Pandawa No. 1, Kartasura, Sukoharjo, Jawa Tengah Kode Pos. 57168

Phone (+62271) 781516 Fax: (+62271)782336

E-mail: shirkahjournal@iainsurakarta.ac.id; shirkahiainsurakarta@gmail.com

Website: http://shirkah.or.id/ 


\section{Shirkah}

Journal of Economics and Business

Vol. 4, No. 1, January-April 2019

ISSN: 2503-4235 (p); 2503-4243 (e)

\section{Table of Contents}

\section{Articles}

Datien Eriska Utami

Identifying Financial and Non-Financial Factors as

the Determinant of Sukuk Rating in Indonesia

JM Muslimin

Halal Product Guarantee in

Indonesia Regulation and Social Inclusion

Isnan Indriati

Muh. Rudi Nugroho

Kuznet's Hypothesis and Ibn Khaldun's Socio-Economic Dimensions

Lucky Nugroho

Ahmad Badawi

Nurul Hidayah

Indonesia Islamic Bank Profitability 2010-2017

Aam Slamet Rusydiana

Lina Marlina

Lina Nugraha Rani

Malmquist Productivity Index on Islamic Economics and

Finance Research

Ahmad Farras Adibuddin

Doddy Setiawan

Bambang Sutopo

The Recent Development of Islamic Economic Studies in Indonesia 


\title{
Indonesia Islamic Bank Profitability 2010-2017
}

\author{
Lucky Nugroho \\ Faculty of Economics and Business, Universitas Mercu Buana, Jakarta \\ lucky.nugroho@mercubuana.ac.id \\ Ahmad Badawi \\ Faculty of Economics and Business, Universitas Mercu Buana, Jakarta \\ ahmad.badawi@mercubuana.ac.id \\ Nurul Hidayah \\ Faculty of Economics and Business, Universitas Mercu Buana, Jakarta \\ nurul.hidayah@mercubuana.ac.id
}

\begin{abstract}
This study proposes to determine the board management structure, bad debt, and efficiency of the profitability of the Islamic banks during 2007-2017 period. The quantitative data has been analyzed by using multiple regression analysis to determine the effect of independent variables on the variable dependent. Furthermore, the statistic tools used in the data process is Stata version 13. This study shows that the board of directors of the parent bank has a negative and significant influence on profitability. The problem financing has a negative and significant effect on profitability. Likewise, the ratio of operational costs also has a negative and significant effect on profitability. Thus, the existence of a parent bank's board of management to improve the performance of Islamic banks needs to be considered because it has not been able to provide an optimal contribution. In addition, the significant amount of financing quality and the use of inefficient operational costs have been a problem of improving profits from Islamic banks.
\end{abstract}

Keywords: Parent Bank, Bad Debt, Efficiency, Profitability, Islamic Banks

\section{Introduction}

In 1997, due to the monetary crisis, sixteen conventional banks were liquidated. However, in the period of financial crisis, the bank 
liquidation does not occur in Islamic banks. It attracts academician to do further research on the stability of Islamic banks in times of crisis (Alim, 2014). The financial services authority report in 2018 revealed that the return on assets (ROA) in the Islamic banking industry in the period of 2012 to 2017 had experienced an increasing trend, although the ROA in the Islamic banking industry had not been as good as that of 2012, and also below the ROA of conventional banking industry. The ROA conditions of the Islamic banking industry and conventional banks are shown in graph 1 .

\section{Graph 1.}

Return on Assets of Islamic Banks Versus Conventional Banks

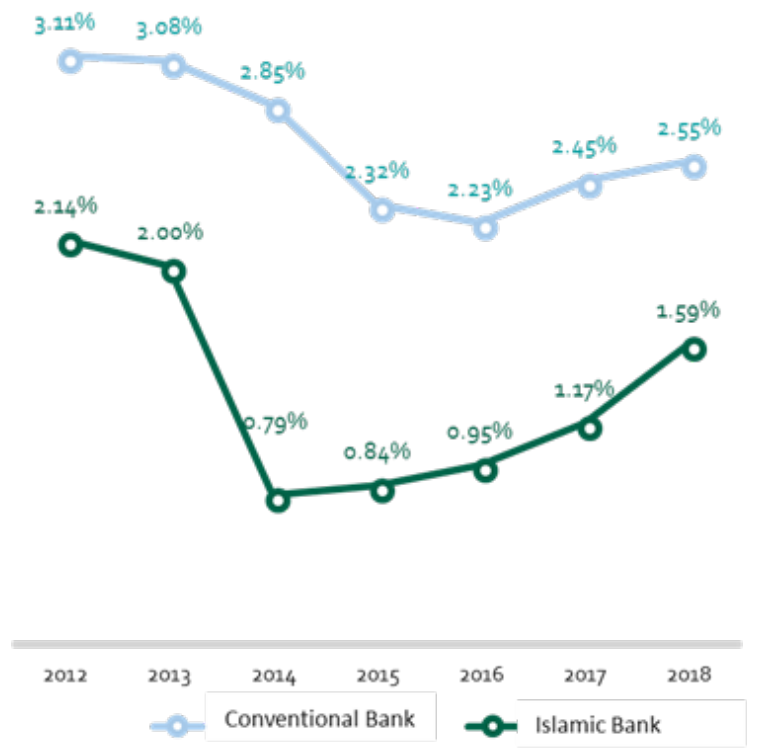

Source: Financial Service Authority (OJK) data already processed

By the graph 1, the conventional ROA of Islamic banks has fluctuated so that the financial stability of Islamic banking has not been better than the stability of conventional banking. At present, the 
majority of Islamic banks in Indonesia are owned by conventional banks, including Islamic banks, which have the largest market share in Indonesia, while the majority of shares are owned by state-owned banks (StateOwned Enterprises). Such sharia banks that controls the market share in Indonesia as Bank Mandiri Syariah, BNI Syariah and BRI Syariah are the government-owned bank, which also has owned conventional bank such as Bank Mandiri, BNI and BRI (Nugroho \& Anisa, 2018; Wirman Syafei et al., 2013).

The growth of Islamic banking industry in Indonesia must also be accompanied by improving the performance of Islamic banks to gain public trust. In maintaining the level of quality and performance of loans, such banks have paid attention to the level of capital adequacy of banks affected by credit risk or financing where there is a possibility of loss as a result of not paying back the credit provided to the customer. Thus, if there is a problem loan, the bank will suffer losses and affect reducing profits. According to Adnan \& Firdaus (2006), the ratio commonly used in measuring bad financing is non-performing loans or financing (NPL/ NPF).

Furthermore, based on graph 2 below, it can be explained that NPF banks in the past three years have experienced quality improvements. The quality improvement was indicated by the decreasing ratio of the period of 2015 to 2018. However, when compared to NPF in conventional banking, the NPF of Islamic banks still has to be improved in quality. Through selective financing and improvement of the competency of the account officer, it can be anticipated from the occurrence of bad debt in the future. 
Graph 2. Non-Performing Financing of Islamic Banks Versus Conventional Banks

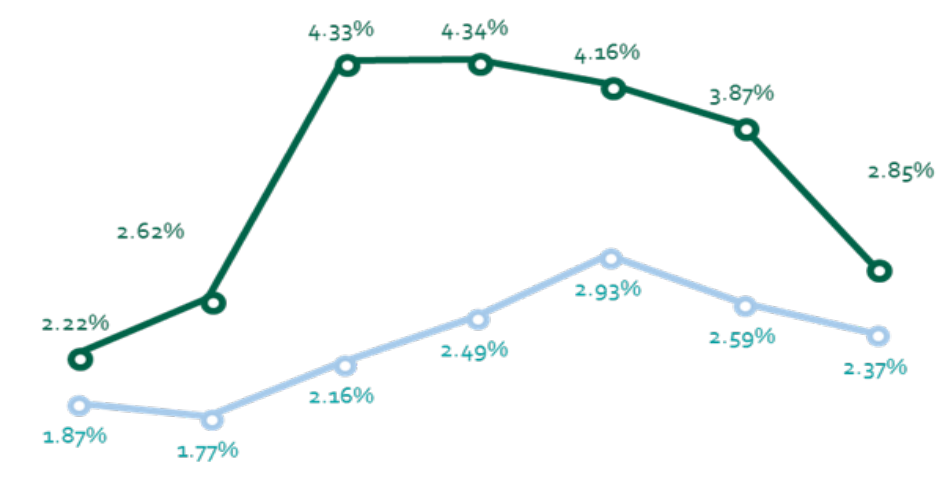

\begin{tabular}{|c|c|c|c|c|c|c|}
\hline 2012 & 2013 & 2014 & 2015 & 2016 & 2017 & 2018 \\
\hline
\end{tabular}

Source: Financial Service Authority (OJK), data already processed

An alternative to maintaining bank remains not in carrying out its business transactions in addition to improving the intermediation function to the public only, but also able to optimize the use of costs. For the banking industry, the use of cost optimization becomes a vital role, since along with the low costs incurred by the bank and compensated with the welfare of the employees, it will increase the loyalty. Increased loyalty from employees can take an impact the increased motivation to work from employees who indirectly have an impact on the increase in the bank's revenue. In addition, the effectiveness in the management of costs, the sharia bank can be able to compete with conventional banks; in doing so it is unusual for the community to conduct transactions with sharia banks. 
However, when referring to the graph 3 below, the ratio of operational costs to the operating income of sharia banks is still not as good as that of conventional banks. Therefore, sharia banks require proper management in order not to occur waste in the expenditure of costs used in operations such as labor costs, promotion costs, general and administrative costs, and investment costs for IT and non IT (Cooper \& Kaplan, 1990; Donsyah Yudistira, 2004; Maudos et al., 2002).

\section{Graph 3. Cost Efficiency Ratio of Islamic Banks Versus Conventional Banks}

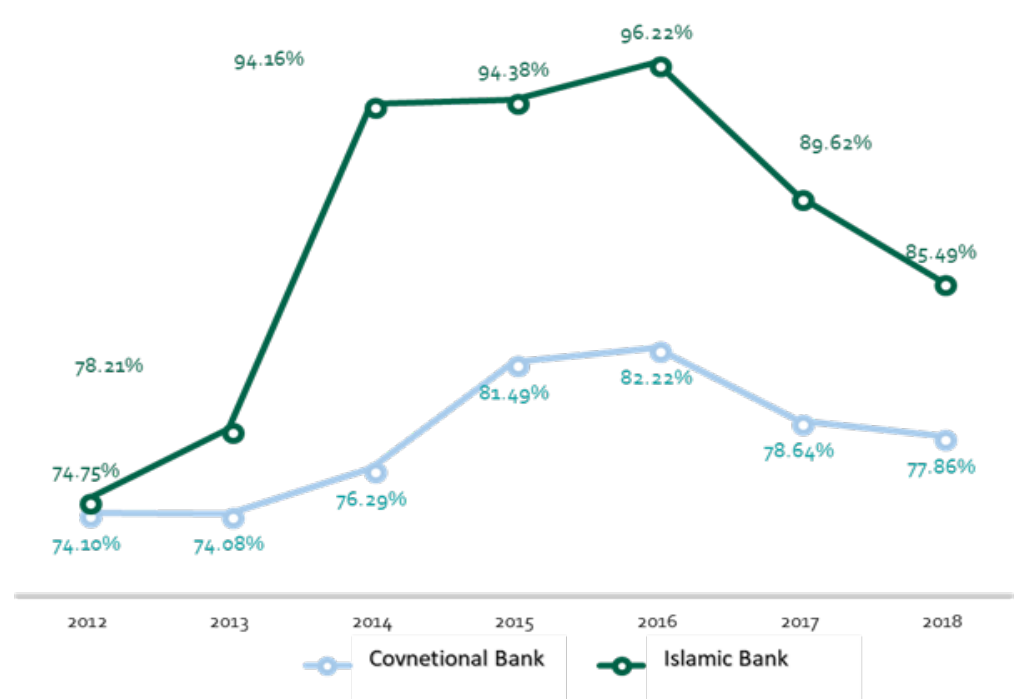

Source: Financial Service Authority (OJK) data already processed

There is a weakness in the sharia bank industry in Indonesia, which is the majority of sharia banks still owned by conventional banks. In doing so, the operational and management of sharia banks has referred to that of conventional banks (Nugroho \& Anisa, 2018; Prasetiyo, 2011). In addition, sharia banks must be able to be independent in the conduct 
of sharia principles and sharia purposes (maqhasid sharia), it provides the Muslim society to transact in sharia banks aimed at carrying out Islamic teachings. Quoting Fahmi (2012), instruction to totality in the Islamic religion is listed on QS. Al-Baqarah verse 115, which meaning: “ ... and to Allah belongs the east and the west. So wherever you [might] turn, there is the Face of Allah. Indeed, Allah is all-Encompassing and Knowing." Islam is a comprehensive religion with the principles of sharia which are not only implemented only in the worship aspect, but also on all aspects of life, such as political, legal, socio-cultural, and economic aspects (Hidayah et al., 2018; Mujib, 2005).

Sharia banks, as banks running operations based on sharia principles, should be able to maintain the trust of the people not only from the product side that has complied with the Islamic teachings and principles, but also able to give a social impact. Thus, the management of sharia banks also requires specialized competencies that not only understand banking operations but to manage banks also understand sharia values and principles. If conventional bank managers succeed at managing the banks, it does not mean that when s/he leads Islamic banks, it will guarantee being successful. As a manager, s/he must be implemented in the behavior and attitudes of the Islamic bank leadership. However, the phenomenon of sharia bank leadership has currently been dominated by the management of the parent bank. Therefore, the underdeveloped business of Islamic banks is due to a gap in the capacity of the management of Islamic banks, which is originated from conventional banks, related to understanding Islamic principles and values.

The business sustainability has highly been dependent on the revenues and profits that the company has earned, including sharia banks (Stubbs \& Cocklin, 2008). In a business ethics perspective, profit has gained in a good way, and must not acquire it by dissocializing all means. 
The implementation of business ethics in the company has been reflected by the good governance, namely the implementation of the principles of transparency, accountability, responsibility, and fairness (Abu-Tapanjeh, 2009; Bedicks \& Arruda, 2005; Sholihin, Harnovinsah, \& Aulia, 2018). Furthermore, carrying out business activities, sharia banks has combined financial aspects with morality and religiosity. Therefore, sharia banks have a social and spiritual responsibility to the community because the business orientation not only to achieve the worldly welfare but also for safety in the hereafter. Business competition is inevitable, but sharia banks should prioritize the principles of justice and prohibit the following activities: providing under standard wages, manipulating financial statements and other activities which ultimately harm the community.

Following the above phenomenon related to the high NPF condition of Islamic banks compared to conventional banks (the graph 2), there is a gap where Islamic banks should have lower NPF. Islamic banks that have an operational basis with Islamic principles should have better quality financing compared to conventional banks. Sharia principles related to understanding shariah principles that include maqasid sharia, maslahah, and falah should be embedded in the customer's perspective and also the view of internal parties from Islamic banks (Arafah \& Nugroho, 2016; Nugroho et al., 2019)discussion on this paper limited by questions: (i. Therefore, the development of Islamic banks is the responsibility of all parties. The ability of Islamic banks to manage their business has been on target, which means that all expenses and use of fees from Islamic banks promote the principles of good governance. Islamic banks have greater operational costs compared to conventional banks (the graph 3). Meanwhile, sharia principles and sharia values teach that in managing sharia banks, wasteful behavior should be avoided (Fatahillah, 2013; Wahyuni, 2013). 
Related to Islamic bank management which has been dominated by parent bank management (conventional bank), this study aims to examine such questions as: is there an influence from parents' bank management on profitability (ROA)? is there an effect of bad financing ratio on profitability (ROA)? and, is there an influence of the cost efficiency ratio on profitability (ROA)? Nevertheless, this research is expected to contribute to the understanding of sharia banking operations, and provide input related to the management of profitability for the board management of sharia banks.

\section{Considering Agency Theory}

In agency theory, agency relationships arise when one or more people employ others to provide a service and delegate decision-making authority to the agent which may be arise asymmetry information (Jensen \& Meckling, 1976; Willenborg \& McKeown, 2000)we find that the presence of a GC opinion is positively related to whether a stock delists (for deleterious reasons. Regarding this research, investors, owners of funds and/or shareholders and governments act as authorizing parties (principals), while the bank is the party receiving authority (agent). The relationship of agency and banks has been more complex than that of non-bank companies (Gutner, 2005; Siringoringo, 2012). In this study, the agency relationship has been indicated by the majority of sharia banks which has been shared with conventional banks. It important to note that the conventional banks as the shareholders of sharia banks have an interest in the performance of sharia banks (Nugroho et al., 2017). These interests arise since the performance of a subsidiary will affect the performance of the parent company; the company's report will be consolidated with the company's financial statement to a consolidated financial statement. 
According to Listiana \& Susilo (2012), a consolidated financial statement is a report that presents the merger of the operations of one subsidiary or more with the company's parent. The phenomenon in Indonesia, almost all sharia banks in Indonesia, has been owned by the main bank which is also a conventional bank except the Bank Muamalat. Thus, the parent company through its share ownership can place its employees to become management in subsidiaries. Whereas according to Chairunnisa et al (2013), which refers to the explanation of Article 29 of Law No. 1 of 1995, the company has a special relationship with other companies because of: more than $50 \%$ (fifty percent) of its shares are owned by the parent company; more than 50\% (fifty percent) of votes in the General Meeting of Shareholders controlled by the parent company; and control over the running of the company, appointment and dismissal of directors and commissioners is strongly influenced by the parent company. Furthermore, according to Satibi et al (2018), conflicts of interest in Islamic banks between agents and principals will not happen because of the similar objectives, namely to implement sharia principles (maqashid shariah, maslahah, falah). There are no more personal, group and company interests. Islamic banks as entities not only prioritize profits, but have social goals such as overcoming social problems: alleviating poverty, cutting unemployment, and preserving the surroundings.

The parent bank management, which is its directors originated from conventional banks, shows the interests of shareholders aiming to ensure that investments can provide optimal results. These directors from the parent bank should have an impact on increasing the profitability of Islamic banks because it is considered that they have a lot of experience, such as training and better education. This fact is undeniable, considering for an example Bank Rakyat Indonesia (BRI) as the oldest conventional bank which was established since 1896, compared to the oldest Islamic 
banks (Bank Muamalat) which was established in 1992 (Wulandari, 2018). This fact has been striking the Islamic bank's internal capabilities compared to conventional bank employees both in terms of quantity and quality aspects. In line with this, according to Rusydiana (2016) and Satibi et al (2018) Islamic bank human resources are still lacking in terms of both quality and quantity; it is expected that the conventional banking management can support good quantities and employee competency in that of Islamic banks. However, it should also be noted that in order to lead and manage Islamic banks, they must have sufficient knowledge related to the concepts and operational principles of Islamic banks, which of course are different from conventional banks. In addition, the impact of conventional banks dependency will be stronger if too many Islamic banks use labor from conventional banks, and take an effect the work culture of Islamic banks. There is a possibility that the increasing number of Islamic bank workers from conventional banks can reduce Islamic values.

Asset quality is all the total assets owned by the bank with the intention to obtain the expected income. One of the calculations and formulas for the asset quality ratio used by rating agencies recognized by Bank Indonesia (Central Bank) is non-performing financing (NPF). The NPF ratio shows the quality of credit assets that have substandard collectability, doubtful collectability and bad collectability of the total financing. The greater the NPF indicates that the bank faces problem loans so that the return on community funds (savings) in the bank will be problematic and have an impact on decreasing profits at the bank (Drake et al., 2009). In addition, the higher the NPF, the more available capital in banks because the increasing number of bad loans will reduce the amount of available capital because if profits decline and even experience losses, then the capital held by the bank will be used to finance bank operations. 
Business efficiency means that costs incurred to produce profits are smaller than the profits derived from using these costs. Banks that are inefficient in their business activities will result inability to compete in raising funds from the public and inchanneling these funds to the public as the bank's business capital. With the efficiency of banking institutions, especially the efficiency of operational costs, the optimal level of profit will be obtained. The impact of optimal profits is the increase in the amount of funds channeled, more competitive costs, improved service to customers, and increased public trust in banks (Sari, 2017; Sukarno \& Syaichu, 2006). The efficiency ratio used to measure the ability of bank management to control operational costs against operating income. Operating costs which is smaller than operating income shows the more efficient of the operational costs incurred by the bank. The possibility of a bank getting losses is reduced (Rhoades, 1998).

Profit for the company is very necessary because of the survival of the company. To make a profit, the company carry out operational activities. This operational activity can be carried out if the company has the resources. Company resources are listed on the balance sheet, and the relationship between the elements that make up the balance sheet can be indicated by financial ratios. The financial ratio functions as a dashboard to show the financial health of the company for a certain period. Therefore, financial ratios are useful for defining the effectiveness of the relationship between financial ratios and economic phenomena.

Profit provides a positive signal about the company's future prospects about company performance. With the earnings growth that proceeds to increase from year to year, it will offer a positive signal to the community and all stakeholders regarding the company's operation (Rhoades, 1998). Good corporate profit growth reflects that the company has good expectations and investment funds from investors will also be 
secure (Shaffer, 2002; Von Thadden, 2004). Thus, if the profitability ratio (ROA) of Islamic banks has a good performance, then as an institution based on sharia principles will play a role and contribute more to the welfare of society (Choudhury \& Hussain, 2005). There is a verse in the Qur'an that deals with the good benefits of commerce (business) where Allahhas invited humans to seek benefits from this earth, with the condition that they are always being grateful.

One form of gratitude is in the form of giving kindness to others. The company's goal to achieve maximum profit should be accompanied by the company's goal to share with fellow human beings, nature and the environment, both sharing in the form of giving part of profits, sharing knowledge and technology, and sharing in other ways that are considered beneficial for social well-being. According to Karim (2011) all profits earned by the company should not make the company owner become stingy and arrogant, because with increasing assets, a company must be more generous and willing to share which stated in QS. Al-Munafiqun verses 9-10, meaning "O you who have believed, let not your wealth and your children divert you from remembrance of Allah. And whoever does that then those are the losers. And spend [in the way of Allah] from what We have provided you before death approaches one of you," and he says, "My Lord, if only You would delay me for a brief term so I would give charity and be among the righteous."

\section{Research Method}

This study uses panel data, namely all Islamic banks with a total of nine banks and have complete data for the period 2007-2017. Furthermore, from these data, a total of 71 observations were obtained, namely all Islamic banks which published complete information in accordance with the criteria of the variables in this study. The mechanism selecting the data as follows: 
Table 1. Determine of Sample Mechanism

\begin{tabular}{|l|c|}
\hline \multicolumn{1}{|c|}{ Steps in determining the sample } & Number of Samples \\
\hline $\begin{array}{l}\text { Sharia Commercial Banks (Bank Umum Syariah- } \\
\text { BUS) registered with the Financial Services } \\
\text { Authority (OJK) in the period (2010-2017) }\end{array}$ & 13 \\
\hline $\begin{array}{l}\text { Sharia Commercial Bank (BUS) that does not have } \\
\text { a Parent Company }\end{array}$ & -3 \\
\hline Outlier data & -1 \\
\hline & 9 \\
\hline Observation Year & 8 \\
\hline & 72 \\
\hline There is one bank whose data was incomplete in & -1 \\
\hline Total & 71 \\
\hline
\end{tabular}

\section{Operational Variable}

The independent variable used in the study was the management from parent company, non-performing financing and cost efficiency. Meanwhile, the dependent variable is profitability or return on assets. The operational variables in this study can be shown in table 2 as follows:

Table 2. Operational Variable

\begin{tabular}{|c|c|c|c|}
\hline Variable & Definition & Formula & Scale \\
\hline $\begin{array}{l}\text { Management from } \\
\text { Parent Company } \\
(\mathrm{X} 1) \\
\end{array}$ & $\begin{array}{l}\text { Directors of Islamic banks } \\
\text { appointed by the parent } \\
\text { company }\end{array}$ & $\begin{array}{l}\text { Directors from Parent } \\
\underline{\text { Company All Directors }}\end{array}$ & Ratio \\
\hline $\begin{array}{l}\text { Non Performing } \\
\text { Financing }(\mathrm{X} 2)\end{array}$ & $\begin{array}{l}\text { Financing whose } \\
\text { installments are not } \\
\text { on time and have sub- } \\
\text { standard, doubtful and loss } \\
\text { categories }\end{array}$ & $\begin{array}{l}\underline{\text { Bad financing of Islamic }} \\
\underline{\text { Bank All Financing of }} \\
\text { Islamic Bank }\end{array}$ & Ratio \\
\hline $\begin{array}{l}\text { Cost Efficiency } \\
\text { Ratio (X3) }\end{array}$ & $\begin{array}{l}\text { Operational costs incurred } \\
\text { compared to operating } \\
\text { revenue }\end{array}$ & $\frac{\text { Operating Cost of Islamic }}{\underline{\text { Bank Operating Revenue }}}$ & Ratio \\
\hline
\end{tabular}




\begin{tabular}{|c|c|c|c|}
\hline $\begin{array}{l}\text { Return on Asset } \\
\text { (Y) }\end{array}$ & $\begin{array}{l}\text { Asset Return Rate is a } \\
\text { profitability ratio that } \\
\text { shows the percentage of } \\
\text { profit (net profit) obtained } \\
\text { by the company with } \\
\text { respect to the overall } \\
\text { resource or the average } \\
\text { amount of assets }\end{array}$ & $\frac{\text { Return of Islamic Bank }}{\text { Asset of Islamic Bank }}$ & Ratio \\
\hline
\end{tabular}

Based on table 2 above, the research equations obtained are as follows:

$$
R O A=\alpha+\beta 1 P R+\beta 2 N P F+\beta 3 C E R+
$$

Remark:

ROA : Return on Asset

$\alpha \quad$ : Coefficient

PR : Board Management/Director from Parent Company Ratio

NPF : Bad Financing Ratio

CER : Operational Cost Ratio

\section{Result and Discussion}

The results of processing independent variables and dependent variables using statistical statistic tools Stata version 13, and regression analysis methods, the following results are obtained: 
Table 3. Regression Statistic of Parents Management (PR), Bad Debt (NPF), Efficiency (CER), and Profitability (ROA)

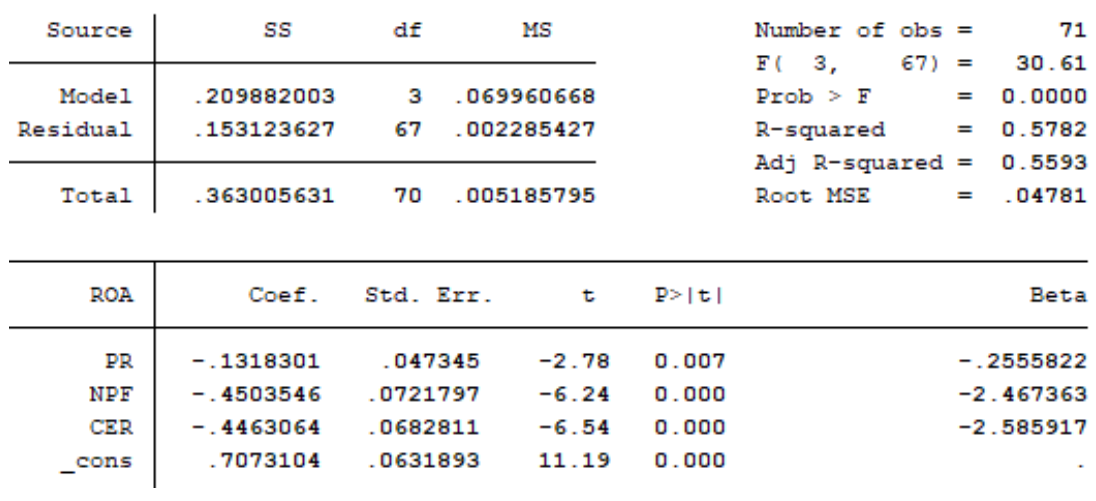

Source: Regression by Stata Version.13

Referring to the statistical results in table 3 above, the influence of all independent variables, including management ratios from the parent bank, problematic financing ratios, and efficiency ratios have a significant effect on profitability or ROA. This significant effect is indicated by the R-squared value of $57.82 \%$. Furthermore, the management variable from the parent bank has a negative and significant effect on return on assets. The greater number of managements from the parent banks will reduce the ROA of Islamic banks. Whereas problematic financing also has a negative and significant impact on profitability in which the increase in problematic financing will have an impact on decreasing profits; the ROA of Islamic banks also decreases. Likewise, with operational costs, the higher costs incurred will have an impact on the low income from Islamic banks which will reduce ROA. The equation from the statistical results in table 3 are as follows:

$$
R O A=\alpha-0.1318 P R-0.4503 N P F-0.4463 C E R+\varepsilon
$$

The establishment of Islamic banks in Indonesia is inseparable from the involvement of conventional banks. All Islamic banks are subsidiaries of 
conventional banks except Bank Muamalat and Bank Aceh. In accordance with the results, the number of directors originating from the parent bank will reduce the profitability or ROA of Islamic banks. Decreasing ROA is due to the fact that the number of directors of the parent bank must be further analyzed. In fact, the assumption is that the parent bank will provide the best employees to work for subsidiaries (Islamic banks), and employees which are more experienced than Islamic banks.

Some possibilities can occur which include several considerations. Managing Islamic banks with conventional banks is different; special approaches are needed to compromise Islamic values and sharia principles which are not found in conventional banks. The low tight up of the board of directors from conventional banks would be undeniable to increase the performance of Islamic banks. It is possible that there is an aspect of lack of ownership of the board of directors, because they work in Islamic banks for appointments from the parent bank, and at some time there is a possibility of returning to work for the parent bank. Along with the presence of the directors of the parent bank, there is the possibility of increasing the overhead costs of Islamic banks to pay for the operations of the management board.

Reconsidering the number of directors in Islamic banks which are originated from the parent bank has not had a positive impact on the ROA of Islamic banks. Some characteristics must be possessed as leaders in Islamic banks that are not necessarily owned by employees at conventional banks. According to Lailatul (2017), the characteristics of sharia bank leaders must have good morals. As for leaders with good morals must have the following characteristics consistency (istiqamah), humble (tawadu), hard work (tawakal), sincerity (ikhlas), totality (kaffah), balance (tawazun) and integrity (ihsan). 
Problematic financing is still an obstacle to Islamic banks because, with the many problems financing in Islamic banks, it will trigger an impingement on the difficulty of liquidity of the Islamic bank (Soekapdjo et al., 2019). Problematic financing can be slimmed down through increasing literacy from customers related to their responsibility for the money they borrow. When someone takes a debt, it must really be considered the ability to pay so that it can be predicted that the debt can be repaid properly. According to Cahyadi (2014), Islam allows debt because debt is part of helping fellow human beings (hablun minan naas) as mentioned in the Qur'an, al-Maidah, verses 2 which meaning " $O$ you who have believed, do not violate the rites of Allah or [the sanctity of] the sacred month or [neglect the marking of] the sacrificial animals and garlanding [them] or [violate the safety of] those coming to the Sacred House seeking bounty from their Lord and [His] approval."

However, the Prophet Muhammad indeed allowed debt, but the Prophet also taught the people to avoid debt because debt would bring concern and humiliation if it was used not in accordance with religious guidelines or intended for bad deeds. This was confirmed by the Prophet in another hadith narrated by Baihaqi, "Be careful you are in debt, in fact, the debt brings worry at night and causes humiliation during the day." Some considerations that need to be understood and when taking loans are as follows: debt only in force/difficult circumstances; do not procrastinate in paying off debt; delaying repayment of debt is an unfairness; if there is a late payment due to financial difficulties, let the person in debt notify the person who makes the loan; and use the loan money as well as possible while realizing that the loan is a mandate that must be returned.

Efficiency has an important role to improve the competitiveness of a company. Efficiency must be based on the effectiveness of the use of costs in accordance with optimal results for Islamic banks. This study found that 
the higher ratio of operational costs will take an impact on decreasing ROA. The use of costs, both operational expenditure and capital expenditure to carry out business operations of Islamic banks, must be calculated properly so that their use does not exceed the established budget According to Arief (2012) wastefulness and over-exaggeration in the Islamic perspective are strictly prohibited, it is stated in the Qur'an, al-Isra, verse 27, meaning "Indeed, the wasteful are brothers of the devils, and ever has Satan been to his Lord ungrateful." Besides that, there is also mentioned in the Qur'an, alA'raf verse 31, meaning "O children of Adam, take your adornment at every mosque, and eat and drink, but be not excessive. Indeed, He likes not those who commit excess." Islamic banks which have an afterlife orientation must be able to innovate according to the needs and demands of the people, without reducing Islamic values. The simplicity of Islamic banks cannot be construed as reducing the competitiveness of Islamic banks.

\section{Conclusion}

The board of directors originating from the parent bank has a negative and significant influence on the ROA of Islamic banks. The placement of parent bank employees (conventional banks) in Islamic banks needs to be reconsidered because they have not provided optimal benefits. Along with the limited number of human resources who have specialized competencies in understanding sharia principles and values, a collaboration between educational institutions and the Islamic industry is needed to adjust the demand and supply of labor in the sharia industry.

Problematic financing has a negative and significant effect on ROA of Islamic banks. Problem financing for Islamic banks needs special attention because it has a direct impact on the performance and quality of Islamic bank financing in Indonesia, which is not yet better with the quality of credit at conventional banks. Furthermore, problematic financing can be 
mitigated through increasing sharia financial literacy to customers and also improving the quality of proper financing analysis from internal Islamic banks through adequate training and training for sharia bank employees;

The operational financing ratio has a negative and significant effect on the ROA of Islamic banks. Sharia bank operations must be more efficient by investing in digital platform-based services for the retail segment. In addition, Islamic banks should have a more simple and effective organization. The current phenomenon of many Islamic bank organizational structures that duplicate the parent bank even though the size and focus of the business are different.

Islamic banks must be able to introduce and improve literacy, both to internal employees and the public. Good literacy amongst the leaders of Islamic banks will raise the ability to manage the banks in accordance with Islamic values and principles. In addition, problem financing can also be reduced through awareness of the borrower in accordance with the precepts of faith, that the loan must be paid back. Likewise, the use of monetary values, must be adapted to the needs and not excessive. This study focuses on the performance of Islamic banks from which return on assets (ROA) is an indicator. Therefore, further research related to the effectiveness of bank organizations and the application of good governance in Islamic banks is being suggested. 


\section{References}

Abu-Tapanjeh, A. M. (2009). Corporate governance from the Islamic perspective: A comparative analysis with OECD principles. Critical Perspectives on Accounting, 20(5), 556-567. https://doi.org/10.1016/j. сра.2007.12.004

Adnan, M. A., \& Firdaus, F. (2006). Evaluasi Non Performing Loan (NPL) Pinjaman Qardhul Hasan (Studi Kasus di BNI Syariah Cabang Yogyakarta). Jaai, 10(2), 155-171.

Alim, S. (2014). Analisis Pengaruh Inflasi dan BI Rate terhadap Return on Assets (ROA) Bank. Jurnal Ekonomi Modernisasi, 10(3), 201-220. https://doi.org/http://dx.doi.org/10.21067/jem.v10i3.785

Arafah, W., \& Nugroho, L. (2016). Maqhashid Sharia in Clean Water Financing Business Model at Islamic Bank. International Journal of Business and Management Invention (IJBMI), 5(2), 22-32. Retrieved from http://www.ijbmi.org/papers/Vol(5)2/Version -3/ D05203022032.pdf

Arief, S. (2012). Konsumen Rasional dalam Perspektif Islam. Islamic Economics Journal, 1(1), 17-30.

Bedicks, H. B., \& Arruda, M. C. (2005). Business ethics and corporate governance in Latin America. Business and Society, 44(2), 218-228. https://doi.org/10.1177/0007650305275301

Chairunnisa, M., Alvi, S., Kamello, T., \& Siregar, M. (2013). Pertanggungjawaban Perusahaan Induk Terhadap Perusahaan Anak dalam Hal terjadinya Pencemaran dan/atau Kerusakan Lingkungan Hidup. USU Law Journal, 2(2), 28-39.

Choudhury, M. A., \& Hussain, M. M. (2005). A paradigm of Islamic money and banking. International Journal of Social Economics, 32(3), 203-217. https://doi.org/10.1108/03068290510580760 
Cooper, R., \& Kaplan, R. S. (1990). Measure Costs Right: Make The Right Decision. The CPA Journal, 60(2), 38. Retrieved from http://search.proquest.com/docview/212280893/abstract/ BF37BA0E762842E6PQ/2?accountid=26401

Donsyah Yudistira. (2004). Efficiency in Islamic Banking: an Empirical Analysis of Eighteen Banks. Islamic Economic Studies, 12(1), 1-17.

Drake, L., Hall, M. J. B., \& Simper, R. (2009). Bank modelling methodologies: A comparative non-parametric analysis of efficiency in the Japanese banking sector. Journal of International Financial Markets, Institutions and Money, 19(1), 1-15. https://doi.org/10.1016/j. intfin.2007.05.002

Fahmi, C. (2012). Revitalisasi Penerapan Hukum Syariat Di Aceh. Jurnal Tsaqafh, 8(2), 296-310.

Fatahillah, I. (2013). Implementasi Konsep Etika Dalam Konsumsi PerspektifEkonomi Islam, 13(2), 154-169. https://doi.org/10.24014/ hi.v13i2.978

Gutner, T. (2005). Explaining the Gaps between Mandate and Performance: Agency Theory and World Bank Environmental Reform. Global Environmental Politics, 5(2), 10-37. https://doi. org/10.1162/1526380054127727

Hidayah, N., Nugroho, L., \& Badawi, A. (2018). Socialization and Training for Productive Household Budget for Household Mother In Meruya Selatan Village. ICCD, 1(1), 523-527.

Jensen, M., \& Meckling, W. (1976). Theory of the firm: Managerial behaviour, agency costs and ownership. Strategic Management Journal, 21(4), 1215-1224. Retrieved from http://search.ebscohost.com/ login.aspx?direct=true\&db=buh\&AN=12243301\&site=ehost-live

Karim, A. (2011). Fungsi harta menurut al- qur'an. Jurnal Al-Hikmah, 12(1), 62-75.

Lailatul, M. (2017). Membangun Karakter Siswa Dan Meningkatkan Kecerdasan Spiritual Melalui The Hidden Curriculum di Mi Wahid 
Hasyim Yogyakarta. DAR EL-ILMI: Jurnal Studi Keagamaan, Pendidikan Dan Humaniora, 4(2), 18-34.

Listiana, L., \& Susilo, T. P. (2012). Faktor-Faktor Yang Memengaruhi Reporting Lag Perusahaan. Media Riset Akuntansi, 2(1), 48-64.

Maudos, J., Pastor, J. M., Pérez, F., \& Quesada, J. (2002). Cost and profit efficiency in European banks. Journal of International Financial Markets, Institutions and Money, 12(1), 33-58. https://doi. org/10.1016/S1042-4431(01)00051-8

Mujib, A. (2005). Pengembangan Psikologi Islam Melalui Pendekatan Studi Islam Abdul. Jurnal Psikologi Islami, 1(1), 17-32.

Nugroho, L., \& Anisa, N. (2018). Pengaruh Manajemen Bank Induk, Kualitas Aset, dan Efisiensi terhadap Stabilitas Bank Syariah di Indonesia (Periode Tahun 2013-2017). Inovbiz: Jurnal Inovasi Bisnis, 6(2), 114-122.

Nugroho, L., Badawi, A., \& Hidayah, N. (2019). Discourses of sustainable finance implementation in Islamic bank (Cases studies in Bank Mandiri Syariah 2018). International Journal of Financial Research, 10(6), 108-117. https://doi.org/10.5430/ijfr.v10n6p108

Nugroho, L., Hidayah, N., \& Badawi, A. (2018). The Islamic Banking, Asset Quality: "Does Financing Segmentation Matters" (Indonesia Evidence). Mediterranean Journal of Social Sciences, 9(5), 221-235. https://doi.org/10.2478/mjss-2018-0154

Nugroho, L., Husnadi, T. C., Utami, W., \& Hidayah, N. (2017). Maslahah and Strategy to Establish A Single State-Owned Islamic Bank in Indonesia. Tazkia Islamic Finance and Business Review, 10(1), 1733. Retrieved from http://www.tifbr-tazkia.org/index.php/TIFBR/ article/view/97/106

Nugroho, L., Villaroel, W., \& Utami, W. (2017). The Challenges of Bad Debt Monitoring Practices in Islamic Micro Banking. European Journal of Islamic Finance, 11, 1-11. 
Prasetiyo, L. (2011). Sekolah Tinggi Agama Islam (STAIN) Ponorogo. Kodifikasia: Jurnal Penelitian Islam, 6(1), 1-18.

Rhoades, S. A. (1998). The efficiency effects of bank mergers: An overview of case studies of nine mergers. Journal of Banking and Finance, 22(3), 273-291. https://doi.org/10.1016/S0378-4266(97)00053-8

Rusydiana, A. S. (2016). Analisis Problem Pengembangan Perbankan Syariah Di Indonesia: Aplikasi Metode Analytic Network Process. Esensi, 6(2), 237-246. https://doi.org/10.15408/ess.v6i2.3573

Sari, N. (2017). Manajemen Dana Bank Syariah. Al-Maslahah Jurnal Ilmu Syariah, 12(1). https://doi.org/10.24260/almaslahah.v12i1.341

Satibi, E., Nugroho, L., \& Utami, W. (2018). A Comparison of Sharia Banks and Conventional Banks in Terms of Efficiency, Asset Quality and Stability in Indonesia for the Period 2008-2016. International Journal of Commerce and Finance, 4(1), 134-149.

Shaffer, S. (2002). Competitive bank pricing and adverse selection, with implications for testing the SCP hypothesis. Quarterly Review of Economics and Finance, 42(3), 633-647. https://doi.org/10.1016/ S1062-9769(01)00087-4

Sholihin, M. R., Harnovinsah, \& Aulia, Y. (2018). Analisis Faktor-Faktor yang Mempengaruhi Pengungkapan Corporate Social Responsibility (Studi Empiris Perusahaan Manufaktur yang Terdaftar di Bursa Efek Indonesia). Jurnal Analisa Akuntansi Dan Perpajakan, 2(2), 110-130. https://doi.org/10.25139/jaap.v2i2.1399

Siringoringo, R. (2012). Karakteristik dan Fungsi Intermediasi Perbankan di Indonesia. Buletin Ekonomi Moneter Dan Perbankan, 15(1), 61-84.

Soekapdjo, S., Tribudhi, D. A., \& Nugroho, L. (2019). Pengaruh Fundamental Ekonomi dan Kinerja Keuangan Terhadap Kredit Bermasalah Pada Bank Syariah Di Indonesia. Ekonika: Jurnal Ekonomi Universitas Kadiri, 4(2), 126. https://doi.org/10.30737/ ekonika.v4i2.327 
Stubbs, W., \& Cocklin, C. (2008). Conceptualizing a "sustainability business model." Organization and Environment, 21(2), 103-127. https://doi.org/10.1177/1086026608318042

Sukarno, K. W., \& Syaichu, M. (2006). Analisis Faktor-Faktor Yang Mempengaruhi Kinerja Bank Umum Di Indonesia. Jurnal Studi Manajemen Organisasi, 3(2), 46. Retrieved from http://ejournal. undip.ac.id/index.php/smo

Von Thadden, E. L. (2004). Asymmetric information, bank lending and implicit contracts: The winner's curse. Finance Research Letters, 1(1), 11-23. https://doi.org/10.1016/S1544-6123(03)00006-0

Wahyuni, S. (2013). Teori Konsumsi dan Produksi dalam Perspektif Ekonomi Islam. Jurnal Akuntable, 10(1), 74-79.

Willenborg, M., \& McKeown, J. C. (2000). Going-concern initial public offerings. Journal of Accounting and Economics. https://doi. org/10.1016/S0165-4101(01)00014-3

Wirman Syafei, A., Debyola Widuhung, S., \& Hadi, K. (2013). Penerapan Teknologi (Sistem) Berbasis Islam Pada Bank Syariah Di Indonesia. Jurnal Al-Azhar Indonesia Seri Pranata Sosial, 2(1), 1-11.

Wulandari, S. (2018). Pengaruh Lokasi, Pelayanan, dan Prosedur Pencairan Pembiayaan terhadap Keputusan Anggota Koperasi Mengambil Pembiayaan. Iqtisad, 5(1), 99-124. 


\section{Shirkah Author Guidelines}

Shirkab currently offers two routes to submit manuscripts. We highly recommend to submit the articles which are made using OJS (Open Journal System). Feel free register as author soon through visiting http://shirkah. or.id/index.php/home/user/register. The authors may directly send their manuscripts, along with their resume, to shirkahiainsurakarta@gmail. com. Please prepare your manuscripts, using following guidelines:

1. Manuscript must be written in English. Submitted articles should not have been published or be under review for publication with another journal.

2. Manuscript's length is about $15-20$ pages, typed in one-half spaced on A4-paper size.

3. Manuscript must include an $150-200$ word abstract and keywords.

4. Manuscript must be arranged as follows: Title, Name of Author, E-mail address, Abstract, Keywords, Introduction (including method if any), Discussion, Conclusion, References.

5. Manuscript's titles not more than ten words.

6. Manuscript must be submitted in Microsoft Word or RTF.

7. Arabic words should be transliterated according to the style of International Journal of Middle Eastern Studies.

8. Manuscript references are preferably derived from the up-to-date references.

9. The author's resume should be submitted separately, consisting of at least full name, institutional address, phone number, areas of studies, and recent publications (if any).

10. Shirkab use APA Style 6th edition (2010) as reference format writing. We suggest the use of a reference manager software such as Mendeley, Zotero, and Endnote at templating the citation style. APA Style to be used is as follows: 


\section{Book with single author}

Swann, G. M. Peter. (2014). The Economics of Innovation an Introduction. Cheltenhum \& Northampton: Edward Elgar.

in-text citation: (Swann, 2014)

\section{Articles in reference books}

Alatas, S. F. (2006). Islam and the Science of Economics in Abu Rabi', I.M. The Blackwell Companion to Contemporary Islamic Thought. USA: Willey-Blackwell (pp. 587-606).

in text citation: (Alatas, 2006)

\section{E-Book}

Hackett, Rosalind (2007). "Religous Dimentions of War and Peace: Introduction." Dalam Gerrie ter Haar dan Yoshio Tsuruoka (Ed.), Religion and Society: An Agenda for the 21st Century (h. 3-6). Retrieved from http:// brill.nl.

in text citation: (Hackett, 2006)

\section{Master's thesis, from a commercial database}

McNieI, D. S. (2006). Meaning through narrative: A personal narrative discussing growing up with an alcoholic mother (Master's thesis). Available from ProQuest Dissertations and Theses database. (UMI No. 1434728)

in text citation: (Mc Niel, 2006)

\section{Doctoral dissertation, from an institutional database}

Adams, R. J. (1973). Building a foundation for evaluation of instruction in higher education and continuing education (Doctoral dissertation). Retrieved from http://www.ohiolink.edu/etd/

in text citation: (Adams, 1973) 


\section{Doctoral dissertation, from the web}

Bruckman, A. (1997). MOOSE Crossing: Construction, community, and learning in a networked virtual world for kids (Doctoral dissertation, Massachusetts Institute of Technology). Retrieved from http:/www-static. cc.gatech.edu/--asb/thesis/

in text citation: (Bruckman, 1997)

\section{Journal article with No DOI}

Bourkhis, K., and Nabi, M. S. (2013). Islamic and conventional banks' soundness during the 2007-2008 financial crisis. Journal Metrics, 22(2), 68-77.

in-text citation: (Bourkhis \& Nabi, 2013).

\section{Journal article with DOI}

Ichwan, M. (2012). The Local Politics Of Orthodoxy: The Majelis Ulama Indonesia in the Post-New Order Banten. Journal Of Indonesian Islam, 6(1), 166-194. doi:http://dx.doi.org/10.15642/JIIS.2012.6.1.166-194

In text citation : (Ichwan, 2012)

\section{Abstract as citation}

Hasan, N. (2012). Islamist Party, Electoral Politics And Da'wah Mobilization Among Youth : The Prosperous Justice Party (PKS) in Indonesia. Journal of Indonesian Islam, 6(1), 17-47. Abstract from http://jiis.uinsby. ac.id/index.php/jiis/article/view/97

in text citation : (Hasan, 2012)

\section{Mass media article}

Sahal, Akhmad (2014, March 2). Kiai Sahal dan Realisme Fikih.Tempo Magazine, p. 120.

in text citation : (Sahal, 2014) 


\section{Research report}

Fisher, B. S., Cullen, F. T., \& Turner, M. G. (2000). The Sexual Victimization of College Women. Research Report.

in text citation : (Fisher, Cullen, Turner, 2000)

\section{Monograph}

Routray, Bibhu Prasad (2013), National Security Decision-Making in India (RSIS Monograph No. 27). Singapura: Rajaratnam School of International Studies.

in text citation : (Routray, 2013)

\section{Proceeding article}

Sudibyakto, Hizbaron, D.R., \& Jati, R (Ed.) (2009), Proceeding International Seminar Disaster Theory, Research and Policy. International seminar held by Sekolah Pascasarjana, Universitas Gajahmada, Yogyakarta, 8-9 Desember 2009.

in text citation : (sudibyakto and Jati, 2009)

\section{Paper conference/seminar/symposium}

Janutama, Herman Sinung (2011). "Kraton dan Hubungan Antar Agama." Paper presented in Seminar Kraton dan Panatagama held by Center for the Study of Islam and Social Transformation (CISForm), Yogyakarta, 17 November.

in text citation :(Janutama, 2011)

\section{Online article in web}

Shiva, (2006, February). Bioethics: A Third World Issue. Native-web. Diperoleh dari http://www.nativeweb.org/ pages/legal/shiva.html

in text citation : (Shiva, 2006) 


\section{Online research report}

Kessy, S. S. A., \& Urio, F M. (2006). The contribution of microfinance institutions to poverty reduction in Tanzania (Research Report No. 06.3). Retrieved from Research on Poverty Alleviation website: http://www.repoa.or.tz/documents_storage/Publications/Reports/06.3_Kessy_and_ Urio.pcif

in text citation : (kessy and urion, 2006)

\section{Holy book}

Qur an, $2(25)$

In text citation : (Q. al-Baqarah 2:25).

\section{Encyclopaedia}

Graycar, Adam (1992). Social Welfare Policy. Dalam Mary Hawkesworth dan Maurice Kogan (Ed.), Encyclopedia of Government and Politics (Vol. 1). London: Routledge.

in text citation : (Graycar, 1992)

\section{Interview}

Sultan Hamengkubuwono X (interview, 2011, April 19)

in text citation: (Hamengkubuwono, 2011)

\section{Documentary film}

Steijlen, Fridus (2008). A Day in the Life of Indonesia [documentary film, 58 minutes]. Leiden: KITLV Press.

in text citation : (Steijlen, 2008) 
Vol. 4 No. 1, January - April 2019 